\title{
Intrapreneurial Workplaces And Job Satisfaction: The Case Of Thai Employees
}

Jatuporn Sungkhawan, Southeast Bangkok College and International Advisory Associates, Thailand Bahaudin G. Mujtaba, Nova Southeastern University, USA

Ziad Swaidan, University of Houston-Victoria, USA

Tanin Kaweevisultrakul, Ramkhamhaeng University, Thailand

\begin{abstract}
Today's competitive workplace requires that employees think creatively and take personal responsibility for their work as if they owned the business. Such ideal and perceived ownership can lead to higher productivity and better job satisfaction levels in the workplace. The purpose of this research is to investigate the relationship between corporate entrepreneurship and organizational performance and overall job satisfaction. Using the responses of 450 employees who work in private companies in Thailand, the study found differences in corporate entrepreneurship and overall job satisfaction based on various demographic variables, namely education, occupation, and position. Regarding autonomy/work discretion, there are differences in autonomy/work discretion and demographic profile, which include gender, education level, salary, type of company, and type of business. Implications for practice and recommendations for future research are presented.
\end{abstract}

Keywords: Entrepreneurship; Intrapreneurship; Job Satisfaction; Education; Age; Thailand

\section{INTRODUCTION}

lobalization has created profound and substantial changes for organizations and industries throughout the world. During the entrepreneurial economy of the 1980s and 1990s, companies began to focus heavily on innovation, with emphasis on entrepreneurial thinking (Drucker, 1984). A wealth of popular business literature described a new "corporate evolution" as corporate entrepreneurship or intrapreneurship.

Many companies today are realizing the need for corporate entrepreneurship. This need has arisen in response to a number of pressing problems, including rapid growth in the number of new and sophisticated competitors, a sense of distrust in the traditional methods of corporate management, an exodus of some of the best and brightest people from corporations to become small-business entrepreneurs, international competition, downsizing of major corporations, and an overall desire to improve efficiency and productivity (Hayes \& Abernathy, 1980). There has been a growing interest in the use of corporate entrepreneurship as a means for corporations to enhance the innovative abilities of their employees and, at the same time, increase corporate success through the creation of new corporate ventures (Khanfar, Loudon, and Mujtaba, 2010; Miller \& Friesen, 1985; Pinchott, 1985).

Moreover, corporate entrepreneurship (CE) is a vital component for successful organizational performance and renewal. As such, it has been the subject of study in literature over several decades. In one of the earliest studies, Peterson and Berger (1971) show that entrepreneurial activities help companies to develop new businesses that create revenue streams. According to Burgelman (1983a, 1991), CE activities also enhance a company's success by promoting product and process innovations. Zahra and Covin (1995) assert that CE activities can improve organizational growth and profitability, and, depending on the company's competitive environment, their impact may increase over time. The empirical evidence is compelling that $\mathrm{CE}$ improves company performance by increasing the firm's willingness to take risk, and by pioneering the development of new products, processes, and services (Kuratko, Montagno, \& Hornsby, 1990; Lumpkin \& Dess, 1996; Zahra \& Pearce, 1994). 
During the economic boom period in Thailand (1986-1995), entrepreneurial activity expanded rapidly, at an average rate of 8 percent per annum. However, the onset of the economic meltdown in 1997, political protests in 2008 and 2010, and the recent flooding challenges in the last four months of 2011 have all caused Thailand's entrepreneurial activity to suffer a tremendous blow, with the number of newly established enterprises dipping to the lowest point in more than a decade. During this period, the Thai economy recorded a negative growth rate for the first time in over four decades.

In 1997, the overall economy registered a growth rate of -1.4 percent, followed by a devastating drop of 10.2 percent in 1998. This phenomenon occurred because the entrepreneurial activity in Thailand was not rooted on a strong foundation. Additionally, the process to build entrepreneurship for it to grow and prosper had a vague direction. Moreover, with the emergence of the free market came many competitors from various countries, which ultimately bankrupted many Thai organizations (Somjai, 1995). Because of this, the Thai government encouraged businesses to think further ahead as well as constantly develop innovative products and services for a sustainable growth. Despite the growing interest in innovation and creativity in continuous improvement, little empirical research has examined the impact of $\mathrm{CE}$ on job satisfaction. Job satisfaction is a frequently studied subject in work and organizational literature since employers are concerned with employee retention (Udechukwu and Mujtaba, 2007). This is mainly due to the fact that many experts believe that job satisfaction trends can affect labor market behavior and influence work productivity, work effort, employee absenteeism, and staff turnover. Moreover, job satisfaction is considered a strong predictor of overall individual well-being (Kenney and Mujtaba, 2008; DiazSerrano, Vieira, \& Jose, 2005), as well as a good predictor of intentions or decisions of employees to leave a job (Gazioglu \& Tansel, 2006).

This research attempts to investigate the impact of CE on job satisfaction. Moreover, the aim is not only to add to the increasing body of literature in this area, but also to strengthen theories that were presented by previous researchers. As such, this study seeks to investigate if a significant relationship exists between corporate entrepreneurship (management support, work discretion/autonomy, rewards and reinforcement, time availability and organizational boundary) and job satisfaction. The research will study corporate entrepreneurship environment and job satisfaction in Thailand's firms. It will compare the corporate entrepreneurship environment and job satisfaction by demographic profile. Specifically this study attempts to answer the following questions:

RQ 1: Is there a significant difference among the demographic profiles on corporate entrepreneurship environment?

RQ 2: Is there a significant difference among the demographic profiles on job satisfaction?

RQ 3: Is there a significant relationship between corporate entrepreneurship environment and job satisfaction?

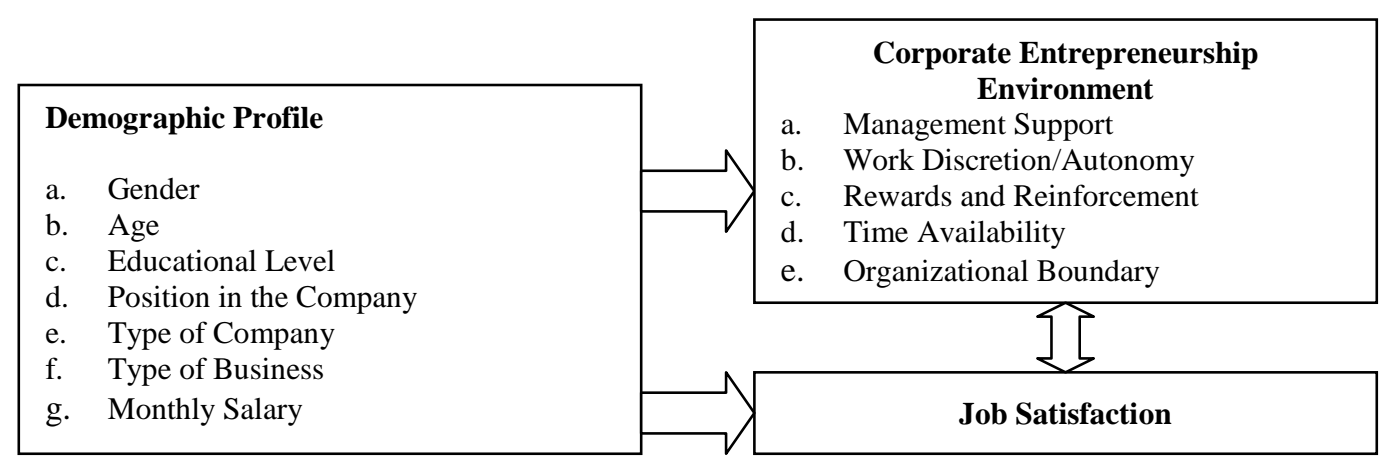

Figure 1 - Framework of the Study 
To give a clearer picture of what the study aims to show, a conceptual diagram is presented in Figure 1. The diagram shows the possible relationship between the selected independent variables of organizational entrepreneurship environment and the dependent variable of job satisfaction.

The study made use of the Corporate Entrepreneurship Assessment Instrument (CEAI), developed by Kuratko and Morris (2002), to measure employees' perception of an organizational factor that supports corporate entrepreneurship activities within the company. For job satisfaction, the researchers utilized the Minnesota Job Satisfaction Questionnaire (MSQ) developed by Weiss and colleagues (1967). To answer the research questions, three statistical tools were used in this study namely t-test, Analysis of Variance (One-Way ANOVA) and Pearson's Product Moment of Correlation.

\section{SAMPLE POPULATION AND DATA ANALYSIS}

The population in this study was the executive MBA students in Bangkok, Thailand, from Kasetsart University, Ramkhamhaeng University, and Burapha University who attended an innovation and change management course which emphasized the importance of corporate entrepreneurship toward innovation and change. The samples were drawn using a convenience sampling method.

A total of 1,000 questionnaires and cover letters were distributed to both the current and graduated students who attended the innovation and change management course in each university within the class and through electronic mail. A total of 450 completed questionnaires were returned, as shown in Table 1 (in the appendix). Majority respondents were female, age category of 31-40 years, bachelor degree graduates (most of them were current MBA students), working for private companies in Thailand, salary per month ranging between 20,00035,000 Baht; sales volume is 100-300 Million Baht; number of employee is 101-300; and the main type of business industry is production sector. Demographic data were summarized and explained by frequency, mean, percentage.

Hypotheses 1 and 2 were examined using T-test and One-Way ANOVA or F-test and continued testing with Multiple Comparisons Test to determine if there are differences found using Least Significant Difference (LSD) methodology.

Hypothesis 3 was examined using Pearson's Correlation Coefficient. The correlation coefficient value is interpreted as follows:

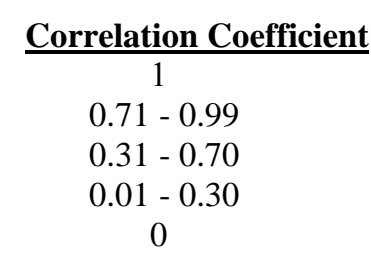

\author{
Meaning \\ Perfect Correlation \\ High Correlation \\ Medium Correlation \\ Low Correlation \\ No Correlation
}

The interpretation of the sign (+, -) as follows:

- $\quad+$ Correlation means that the two variables are correlated in the same direction

- 0 means no correlation

- $\quad$ Correlation means that two variables are correlated in opposite directions.

Table 2 (in the appendix) presents the results of some demographic profiles: gender, age, occupation, position, salary, and company type. In regards to education, 244 (54.2\%) had bachelors' degrees and 206 (45.8\%) had masters' degrees. In regards to sales, 50 of the respondents worked in companies with over 500 million bahts per year. The respondents were from service, manufacturing, retail, import/export, and financial businesses.

Table 3 presents the results of corporate entrepreneurship environment (management support, work discretion, rewards/reinforcement, time availability, and organizational boundaries) by descriptive statistical techniques such as frequency, percentage, mean, and standard deviation. The mean ranges in this study are classified as follow: 


\begin{tabular}{ll} 
Meaning & Mean range \\
\hline Strongly agree & $4.21-5.00$ \\
Agree & $3.41-4.20$ \\
Not sure & $2.61-3.40$ \\
Disagree & $1.81-2.60$ \\
Strongly disagree & $1.00-1.80$
\end{tabular}

Table 4 presents number, percentage, mean, and standard deviation of respondents' perception regarding work discretion factor of corporate entrepreneurship environment. Table 5 shows number percentage mean and standard deviation of respondent's perception regarding rewards/reinforcement factor of corporate entrepreneurship environment. Table 6 shows number percentage mean and standard deviation of respondents' perception regarding time availability factor of corporate entrepreneurship environment. Table 7 shows number percentage mean and standard deviation of respondents' perception regarding oorganizational boundaries factor of corporate entrepreneurship environment.

The analysis of job satisfaction is presented by descriptive statistical techniques: frequency, percentage, mean, and standard deviation. Table 8 shows number, percentage, mean, and standard deviation of job satisfaction. The mean range in this study is classified as follows:

\begin{tabular}{ll} 
Satisfaction Level & Mean of Level \\
\hline Extremely Satisfied & $4.21-5.00$ \\
Very Satisfied & $3.41-4.20$ \\
Satisfied & $2.61-3.40$ \\
Somewhat Satisfied & $1.81-2.60$ \\
Not Satisfied & $1.00-1.80$
\end{tabular}

For this study, t-test, one-way ANOVA, and Pearson Correlation were adopted to examine three main hypotheses (and sub-hypotheses) with a significant level of alpha at 0.05 as the criteria for rejection or no rejection of the null hypotheses.

Hypothesis 1 looked at a comparison of corporate entrepreneurship (management support, autonomy/work discretion, rewards/reinforcement, time availability and organizational boundaries) classified by gender, age, education level, occupation, position, salary level, type of company, sales volume, number of employee and type of business. Table 9 summarizes the results of hypothesis testing. There were differences in corporate entrepreneurship between demographic profiles. There was a difference in autonomy/work discretion, rewards/reinforcement when classified by gender. No significant differences were found for management support, time availability and organizational boundaries. There was a difference in time availability and organizational boundaries when classified by age groups. The age group of 31-40 years was different from the age groups 41-50 years and above 51 years. For organizational boundaries, the age group of 31-40 years was different from the age group of 41-50 years. No difference was found for management support, autonomy/work discretion, and rewards/reinforcement. There was a difference in management support, autonomy/work discretion, and rewards/reinforcement when classified by education level. No difference was found for time availability and organizational boundaries. There was a difference in management support, autonomy/work discretion, rewards/reinforcement, and organizational boundaries when classified by occupations. Government/state enterprise was perceived differently from private employee and own business. Also, for management support, the private employees group had different perceptions than those who owned as a business group. No differences were found for time availability. This study found several other important results and some are mentioned below.

1. There was a difference in management support, autonomy/work discretion and rewards/reinforcement when classified by positions. Staff level perceived differently from business owner, director and manager, especially supervisory level. No difference was found for time availability and operational boundaries. 
2. There was a difference in management support, autonomy/work discretion, rewards/reinforcement, and operational boundaries when classified by salary level. Employees who earned a salary below 20,000 Baht were perceived differently from those who earned 20,001-35,000 Baht, 35,001-50,000 Baht and 50,000 Baht or more respectively. For autonomy/work discretion, people with an income of 20,001-350,000 Baht were perceived differently from those who earned 50,000 Baht and up. No difference was found for time availability.

3. There was a difference in management support, autonomy/work discretion/ rewards/reinforcement, and organizational boundaries when classified by company type. Government sector was different from Thai private companies, and US and European companies. For autonomy/work discretion, government sector was different from Thai private companies, and Japanese and US companies. For organizational boundaries, government sector was different in perception from Thai private companies, Japanese and European companies, and others. For management support, Thai private companies were different from Japanese companies and others. For autonomy/works discretion, Thai private companies were different from Japanese and European companies, and others. For rewards/reinforcement, Thai private companies were different from Japanese companies and others. For management support, Japanese companies were different from the other groups. For rewards/reinforcement, Japanese companies were different from US companies. For management support and autonomy/work discretion, US companies were different from the other groups. Finally, for management support, European companies were different from the other groups. No difference was found for time availability.

4. There was difference in employee perception of management support and organizational boundaries when classified by the organization's sales volume per annum. Organization with a sales volume of 50-100 million Baht were different from organizations with a sales volume below 50 million Bahts, and sales volume of 500 million Baht up was different from sales volume of 50-100 million Baht and 100-300 million Baht respectively. For organizational boundaries, companies with sales volume below 50 million Baht were different from those of 100-300 million Baht and 500 million Baht up, and sales volume 50-100 million Baht was different from 300-500 million Baht and 500 million Baht up. Lastly, sales volume of 100-300 million Baht was different from sales volume of 300-500 million Baht. No difference was found for autonomy/work discretion, rewards/reinforcement and time availability.

5. There was a difference in organizational boundaries when classified by the number of employees. Companies with fewer than 20 employees were perceived differently than those with 21-100 employees, 101-200 employees and 301-500 employees, and companies with more than 500 employees were different from those of 21-100 employees, 101-300 employees and 301-500 employees. No difference was found for management support, autonomy/work discretion, rewards/reinforcement, and time availability.

Furthermore, there was a difference in management support, autonomy/work discretion, rewards/reinforcement, and organizational boundaries when classified by type of business. Import/export businesses were different from service businesses, manufacturing, financial businesses, and others. For autonomy/work discretion, the import/export businesses were different from service businesses; financial businesses were different from manufacturing. For rewards/reinforcement, import/export businesses were different from service businesses and manufacturing; other businesses were different from service businesses and manufacturing. For organizational boundaries, service businesses were different from manufacturing, import/export, and other businesses; manufacturing businesses were different from retail/wholesale, import/export, financial businesses; import/export businesses were different from financial businesses. No difference was found for the time availability factor.

Hypothesis 2 looked at a comparison of job satisfaction classified by gender, age, education level, occupation, position, salary level, type of company, sales volume, number of employees, and type of business. Table 10 summarizes the results of hypothesis testing. There were differences in overall job satisfaction between demographic profiles. The study found that,

1. There was a difference in overall job satisfaction when classified by gender.

2. There was a difference in overall job satisfaction when classified by age groups. The age groups of less than 30 years were different from the group of age 31-40, $41-50$ and over 55 years.

3. There was no difference in overall job satisfaction when classified by educational level. 
4. There was a difference in overall job satisfaction when classified by occupation. Government/state enterprise was perceived differently from private company and self-owned. At the same time, private company was different from self-owned.

5. There was a difference in overall job satisfaction when classified by position. Supervisors were different from owners and managers. Also, staffs were different from owners, directors and managers.

6. In term of salary level, there was a difference in overall job satisfaction. People with salary less than 20,000 Baht were different from those of 20,001-35,000 Baht, 35001-50,000 Baht and over 50,000. People with salary between 20,001-35,000 Baht were different from those of 35,001-50,000 Baht and over 50,000. Also, people with a salary between 35,001-50,000 Baht were different from those of over 50,000.

7. There was no difference in overall job satisfaction classified by company types.

8. With regard to overall job satisfaction and sales volume, there was a difference. Sales volume of more than 500 million Baht was different from those of less than 50 million Baht, 50-100 million Baht, and 100-300 million Baht and 300-500 million Baht.

9. There was no difference in overall job satisfaction when classified by the number of employees.

10. Lastly, there was a difference in overall job satisfaction when classified by type of business. Manufacturers were different from the group of service providers and others.

Hypothesis 3 focused on the correlation between corporate entrepreneurship (management support, work discretion, rewards/reinforcement, time availability and organizational boundaries) and overall job satisfaction. Table 11 summarizes the results of hypothesis testing. There is a positive relationship between corporate entrepreneurship and overall job satisfaction.

Overall, the results show that the employee's perceptions are at the agreed level toward four dimensions of corporate entrepreneurship environment; management support, autonomy/work discretion, rewards/reinforcement, and organizational boundaries with the score of 3.56, 3.57, 3.75 and 3.53 respectively. The research found that the employees' perceptions toward job satisfaction are at the satisfaction level: the mean score is 3.36. The highest score item is "The feeling of accomplishment I get from the job," the next is "The way my job provides for steady employment," and the lowest score is "Being able to keep busy all the time." The mean scores are 3.76, 3.64 and 2.94 respectively. The study found that there is a positive correlation between all factors of corporate entrepreneurship and overall job satisfaction. The degree of relationship of management support, autonomy/work discretion, rewards/reinforcement, and organizational boundaries are moderately positive. For time availability, the degree of relationship with the overall job satisfaction is positively low.

\section{DISCUSSION OF THE RESULTS}

The purpose of this research was to investigate the relationship between CE and overall job satisfaction. Additionally, the study compared corporate entrepreneurship with overall job satisfaction using the demographic profiles.

There were differences in corporate entrepreneurship and overall job satisfaction among the demographic profiles, which include gender, age, education level, occupation, position, salary, type of company, sales volume, number of employee and type of business, and these results are consistent with previous findings. For management support, there were differences when classified by education, occupation, position, type of company, and type of business. This research also found that there were differences in corporate entrepreneurship based on education, occupation and position. Regarding autonomy/work discretion, there were differences in autonomy/work discretion and demographic profiles gender, education level, salary, type of company, and type of business. Such results were in agreement with the previous studies conducted by Adonisi (2003), which revealed that there were differences in autonomy/work discretion when classified by gender, education and position.

For reward/reinforcement, there were differences in rewards/reinforcement and demographic profiles of gender, education level, occupation, position, salary, type of company, type of business. The results were inconsistent with Adonisi's (2003) study that suggested no difference in rewards/reinforcement factor when classified by demographic profiles. There were differences in time availability between the age groups. Such results were inconsistent with Adonisi's (2003) study that indicated no difference in the time availability factor when 
classified by age groups. Relating to organizational boundaries, there were differences in the age group, occupation, salary, type of company, sales volume, number of employees, and type of business. As such, no other research supports the results. Pertaining to overall job satisfaction classified by demographic profiles, including gender, age, educational level, occupation, and type of business, the result was in congruence with Gilmer's (1967) study, which found that there was a difference in job satisfaction based on gender, age, and educational level.

Lastly, there was a positive relationship between every factor of corporate entrepreneurship (management support, autonomy/work discretion, rewards/reinforcement, time availability, and organizational boundaries) and overall job satisfaction, at low to moderate degree of associations. The result was consistent with the study of Adonisi (2003), Hornsby and Kuratko (2003), Kuratko and Hodgettes (2004), and Owens (2003), who stated that all facets of corporate entrepreneurship positively correlated with overall job satisfaction. Therefore, it could be said that if an organization utilized the five antecedents of CE: (1) management support (willingness of top-managers to facilitate and promote entrepreneurial behavior, including championing of innovation ideas and providing necessary resources), (2) autonomy/discretion (top-level managers' commitment to tolerate failure, provide decision-making latitude and freedom from excessive over control and delegate authority and responsibility), (3) rewards/reinforcement (development and use of systems that reward based on performance and significant achievements, and that which encourage pursuit of challenging work), (4) time availability (evaluating workloads to assure time to pursue innovations and structuring jobs to support efforts to achieve short and long term organization goals), (5) organization boundaries (explanations of outcomes expected from organizational work and development of mechanisms for evaluation, selecting, and using innovation), then its employees will be satisfied with both the work and the organization. As a result, it is expected that organizational outputs will be improved in terms of faster service, better quality and cheaper cost (Kenney and Mujtaba, 2007).

In sum, all aspects of CE influenced job satisfaction. With increased job satisfaction, organizational performance is also expected to increase.

\section{MANAGERIAL IMPLICATIONS}

$\mathrm{CE}$ is a vital component for successful organizational performance and renewal. According to Burgelman (1983a, 1991), CE activities enhance a company's success by promoting product and process innovations. Zahra and Covin (1995) asserted that CE activities can improve organizational growth and profitability. This particular study investigated different aspects of entrepreneurship and their impact on organizations. Furthermore, it examined different entrepreneurial practices that may either bring success or failure to companies. Moreover, it looked at the relationship between corporate entrepreneurial practices and job satisfaction.

This study found that all aspects of corporate entrepreneurship, namely management support, work discretion/work autonomy, rewards and reinforcements, time availability and organizational boundaries play an important part in creating success for an organization. Managers should encourage all employees to be innovative. Managers can show their support by quick adoption of employees' ideas, appreciation of people who convey ideas forward, support for small experimental projects, and seed money to get projects off the ground. Work discretion or autonomy enhances job satisfaction. Work discretion also encourages employees to become more creative and/or innovative since it allows more freedom as to how to accomplish the assigned tasks. Therefore, managers should allow a certain degree of autonomy to their employees.

Rewards/reinforcement increases job satisfaction. Managers should not overlook employees who perform their job efficiently. These employees should be properly acknowledged and/or given appropriate rewards such as bonus, promotion, or simply recognition for a job well done. In doing so, employees will become more satisfied with their jobs.

Managers should give employees more freedom in terms of jurisdiction in their work. There should be no rigid operating procedures that employees need to follow in accomplishing their respective tasks. Employees will be more satisfied with their jobs if they do not have to follow strict procedures. In sum, all aspects of corporate entrepreneurship should be incorporated in organizations since CE can lead to better employee job satisfaction and other organizational advantages, such as low absenteeism, low turnover rate, and improved productivity. 


\section{LIMITATIONS AND RECOMMENDATIONS}

There are some limitations to the study, and given that the sample size used for this research is moderately small, a larger sample is needed for the hypotheses to be robustly tested. A larger sample increases generalizability of the findings. Samples obtained from employees who work for foreign companies is limited, thus the generalizability of the findings with regard to corporate entrepreneurship and job satisfaction might be restricted. The method used in the study was mainly paper-and-pencil questionnaires, which possibly led to mono-method bias in the responses gathered.

To generalize the findings, it would be useful to conduct similar research in a broader spectrum of different business sectors. Additionally, future research should be directed to exploring other variables not investigated in this study. Moreover, future studies can also make use of the results of this study as a foundation to find out which among the different factors of corporate entrepreneurship best apply to a specific company's setting in order to develop entrepreneurial activities.

\section{AUTHOR INFORMATION}

Jatuporn Sungkhawan, D.B.A., is a strategic management professional with 20 years of experience in multinational corporations. He has been associated with some of the world's largest companies to include agribusiness, financial service and management consulting. He is a university professor who teaches Strategic Management, Business Research, and Organization Behavior. He earned the Doctorate in Business Administration degree at Nova Southeastern University's H. Wayne Huizenga School of Business and Entrepreneurship, United States. He earned a Masters of Business Administration and a bachelor's degree in Agricultural Economics at Kasetsart University, Bangkok, Thailand. E-mail: dr_jatuporn@yahoo.com or: J_sungkhawan@ hotmail.com

Bahaudin G. Mujtaba, D.B.A., is Professor of Management and Human Resources at Nova Southeastern University's H. Wayne Huizenga School of Business and Entrepreneurship. Bahaudin has served as a manager, trainer and management development specialist in the corporate world as well as a director, department chair and professor in academia for nearly three decades. He is author and co-author of seventeen books in the areas of leadership, coaching, and performance management. His areas of research are management, training, diversity management, and cross-cultural management. (Corresponding author) - E-mail: mujtaba@nova.edu.

Zaid Swaidan's, Ph.D., research focuses on cross cultural marketing and consumer ethics. Over the last decade he has published extensively in such well-regarded academic journals as the Journal of Business Ethics, International Business Review, Journal of Global Marketing, Journal of Marketing Theory and Practice, and Journal of Education for Business. Dr. Swaidan's research has been cited by well over 220 articles from across the globe as of January 2012. Some of these citations have appeared in excellent journals such as the Journal of Business Ethics and the Journal of Global Marketing. E-mail: swaidanz@uhv.edu

Tanin Kaweevisultrakul, Ph.D., is product manager at Diethelm Limited (Thailand). As a product manager, he looked after 2 main principals which include SSL (Durex, Durex play, Scholl, Woodward, Prosport, and Coppertone) and PG (Vicks Vaporub). His main responsibilities include managing sales team, dealing with principals, and managing stock. He completed a doctorate of business administration degree from the Institute of International Studies at Ramkhamhaeng University in Bangkok, Thailand. His dissertation title was: Motivational Drivers Conducive to Individuals' Knowledge Sharing Intentions in Thai Healthcare Industry. His research interests are in the areas of knowledge management, culture, and healthcare management. E-mail: tanin.k@dksh.com

\section{REFERENCES}

1. Adonisi, Mandla. 2003. The Relationship between Corporate Entrepreneurship, Market Orientation, Organizational Flexibility and Job Satisfaction. D.B.A. dissertation, University of Pretoria.

2. Burgelman, Robert A. (1983). A Process Model of Internal Corporate Venturing in the Diversified Major Firm. Administrative Science Quarterly, 28, 223-244. 
3. Burgelman, Robert A. (1991). Intra organizational Ecology of Strategy Making and Organizational Adaptation: Theory and Field Practice. Organization Science, 2, 239-262.

4. Diaz-Serrano, L., Cabral Vieira and Jose (2005). Low Pay, Higher Pay and Job Satisfaction within the European Union: Empirical Evidence from Fourteen Countries. IZA Discussion Papers, 1558, Institute for the Study of Labour.

5. Drucker, Peter F. (1984). Converting Social Problems into Business Opportunities: The New Meaning of Corporate Social Responsibility. California Management Review, XXVI(2), 53.

6. Gilmer, Van Haller B. (1967). Applied Psychology. New York: Mcgraw-Hill.

7. Hayes Robert H. and Abernathy William J. (July/August 1980). Managing our Way to Economic Decline. Harvard Business Review, pp. 66-67. Retrieved on December 07, 2011 from: http://hbr.org/product/managing-our-way-to-economic-decline-harvard-busin/an/R0707L-PDF-ENG

8. Horsnby, J.S. and Kuratko D.F. (2003). The Influence of Corporate Entrepreneurial Culture on Job Satisfaction, Reinforcement Practices and Behaviors. Ball State University: USA

9. Khanfar, N., Loudon, D., and Mujtaba, B. G. (2010). Santorini Restaurant: One Entrepreneur's Start-Up Adventure. Journal of Business Studies Quarterly, 1(2), 70-74.

10. Kenney, M. and Mujtaba, B. G. (2008). Entrepreneurs entering the higher education market to make a difference: The Kenney College of Entrepreneurship. Journal of Business Case Studies, 4(1), 99-112.

11. Kenney, M. and Mujtaba, B. G., (July 2007). Understanding Corporate Entrepreneurship and Development: A Practitioner View of Organizational Intrapreneurship. Journal of Applied Management and Entrepreneurship, 12(3), 73-88.

12. Kuratko, D.F. (1993). Intrapreneurship: Developing Innovation in Corporations. Advances in Global High Technology Management, 3, 3-14.

13. Kuratko, D.F. \& Hodgetts, R.M. (2004). Entrepreneurship: Theory, Process, Practice. Mason, OH; SouthWestern Publishers.

14. Kuratko, D.F., Montagno, R. V. \& Hornsby, J. S. (1990). Developing an intrapreneurial assessment instrument for an effective corporate entrepreneurial environment. Strategic Management Journal, 11, 4958.

15. Kuratko, D.F. and Morris, M.H. (2002). Corporate Entrepreneurship. South-Western College Publishers: Mason, Ohio.

16. Lumpkin, J. T. and Dess G.G. 1996. Clarifying the international orientation construct and linking it to performance. Academy of Management Review, 21, 135-172.

17. Miller, Danny. (1985). Exploring Determinants of Success in Corporate Ventures. Journal of Business Venturing, 1, 87- 105.

18. Owens, Gina Paige. (2003). Factors Affecting Job Satisfaction among Clinical and Counseling Psychology Faculty. University of Kentucky.

19. Peterson, Richard A. and Berger, David G. (March 1971). Entrepreneurship in Organizations: Evidence from the Popular Music Industry. Administrative Science Quarterly, 16(1), 97-106.

20. Pinchot, G. (1985). Intrapreneuring. New York: Harper and Row.

21. Saziye, Gazioglu \& Aysit Tansel (2006). Job satisfaction in Britain: Individual and job related factors. Applied Economics, 38(10), 1163-1171.

22. Somjai, Kesornsiricharoen (1995). The Role and Function of Public Prosecutors in Thailand. 107 ${ }^{\text {th }}$ International Training Course Participants' Papers, Pages 280-307. Retrieved on December 6, 2011 from: http://www.unafei.or.jp/english/pdf/RS_No53/No53 28PA_Kesornsiricharoen.pdf

23. Udechukwu, I. I. and Mujtaba, B. G. (June 2007). Determining the probability that an employee will stay or leave the organization: a mathematical and theoretical model for organizations. Human Resource Development Review, 6(2), 164-184. DOI: 10.1177/1534484307300239.

24. Weiss, D. J., Dawis R. V., England G.P. and Lonfquist L. H. (1967). Manual for Minnesota Questionnaire. ST. Paul: University of Minnesota, Industrial Relations Center.

25. Zahra, Shaker and Covin, Jeffrey (1995). Contextual Influences on the Corporate Entrepreneurship Performance Relationship: A Longitudinal Analysis. Journal of Business Venturing, 10. 43-58.

26. Zahra, S.A. and Pearce J.A. II. (1994). Corporate Entrepreneurship in Smaller Firms: The Role of Environment, Strategy and Organization. Entrepreneurship, Innovation and Change, 3(1), 31-44. 


\section{APPENDIX: LIST OF TABLES}

Table 1 - Sample Sources, Number of the Distributed and Returned Questionnaires

\begin{tabular}{lcc}
\hline Sources & Distributed Number & Return Number \\
\hline 1. Within Class & 500 & 244 \\
2. Electronic Mail & 500 & 206 \\
\hline Total & 1,000 & 450 \\
\hline
\end{tabular}

Table 2 - Number and Percentage of Demographic Profiles

\begin{tabular}{|c|c|c|}
\hline Demographic characteristic & Number & Percentage \\
\hline \multicolumn{3}{|l|}{ Gender } \\
\hline Male & 165 & 36.7 \\
\hline Female & 285 & 63.3 \\
\hline Total & 450 & 100.0 \\
\hline \multicolumn{3}{|l|}{ Age } \\
\hline 30 or under & 120 & 26.7 \\
\hline $31-40$ & 188 & 41.8 \\
\hline $41-50$ & 121 & 26.8 \\
\hline 51 or over & 21 & 4.7 \\
\hline Total & 450 & 100.0 \\
\hline \multicolumn{3}{|l|}{ Occupation } \\
\hline Government and State Enterprise & 95 & 21.1 \\
\hline Private Company & 281 & 62.4 \\
\hline Self-owned & 67 & 14.9 \\
\hline Others & 7 & 1.6 \\
\hline Total & 450 & 100.0 \\
\hline \multicolumn{3}{|l|}{ Position } \\
\hline Owner & 50 & 11.1 \\
\hline Director & 18 & 4.0 \\
\hline Manager & 102 & 22.7 \\
\hline Supervisor & 102 & 22.7 \\
\hline Staff & 178 & 39.5 \\
\hline Total & 450 & 100.0 \\
\hline \multicolumn{3}{|l|}{ Salary } \\
\hline 20,000 or Below & 112 & 24.9 \\
\hline $20,001-35,000$ & 135 & 30.0 \\
\hline $35,001-50,000$ & 96 & 21.3 \\
\hline above 50,000 & 107 & 23.8 \\
\hline Total & 450 & 100.0 \\
\hline \multicolumn{3}{|l|}{ Company type } \\
\hline Government & 86 & 19.1 \\
\hline Thai Private Company & 252 & 56.0 \\
\hline Japanese Company & 53 & 11.8 \\
\hline US Company & 13 & 2.9 \\
\hline European Company & 14 & 3.1 \\
\hline Others & 32 & 7.1 \\
\hline Total & 450 & 100.0 \\
\hline
\end{tabular}


Table 3 - Management Support of Corporate Entrepreneurship Environment

\begin{tabular}{|c|c|c|c|c|c|c|c|c|}
\hline \multirow[b]{2}{*}{ Corporate entrepreneurship environment } & \multicolumn{5}{|c|}{ Perception Level } & \multirow[b]{2}{*}{$X-$} & \multirow[b]{2}{*}{ S.D. } & \multirow[b]{2}{*}{ Meaning } \\
\hline & 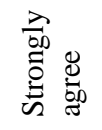 & 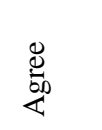 & 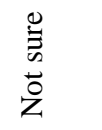 & 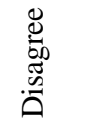 & 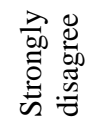 & & & \\
\hline \multicolumn{9}{|l|}{ Management support } \\
\hline $\begin{array}{l}\text { 1. My organization is quick to use improved work } \\
\text { methods. }\end{array}$ & $\begin{array}{c}122 \\
(27.1)\end{array}$ & $\begin{array}{c}276 \\
(61.3)\end{array}$ & $\begin{array}{c}35 \\
(7.8)\end{array}$ & $\begin{array}{c}15 \\
(3.3)\end{array}$ & $\begin{array}{c}2 \\
(0.4)\end{array}$ & 4.11 & .715 & Agree \\
\hline $\begin{array}{l}\text { 2. My organization is quick to use improved work } \\
\text { methods that are developed by workers. }\end{array}$ & $\begin{array}{c}89 \\
(19.8)\end{array}$ & $\begin{array}{c}239 \\
(53.1)\end{array}$ & $\begin{array}{c}83 \\
(18.4)\end{array}$ & $\begin{array}{c}34 \\
(7.6) \\
\end{array}$ & $\begin{array}{c}5 \\
(1.1) \\
\end{array}$ & 3.83 & .870 & Agree \\
\hline $\begin{array}{l}\text { 3. In my organization, developing ideas for the } \\
\text { improvement of the corporation is encouraged. }\end{array}$ & $\begin{array}{c}106 \\
(23.6)\end{array}$ & $\begin{array}{c}257 \\
(57.1)\end{array}$ & $\begin{array}{c}64 \\
(14.2)\end{array}$ & $\begin{array}{c}20 \\
(4.4)\end{array}$ & $\begin{array}{c}3 \\
(0.7)\end{array}$ & 3.98 & .785 & Agree \\
\hline $\begin{array}{l}\text { 4. Upper management is aware of and very receptive to } \\
\text { my ideas and suggestions. }\end{array}$ & $\begin{array}{c}74 \\
(16.4)\end{array}$ & $\begin{array}{c}234 \\
(52.0)\end{array}$ & $\begin{array}{c}109 \\
(24.2)\end{array}$ & $\begin{array}{c}25 \\
(5.6) \\
\end{array}$ & $\begin{array}{c}8 \\
(1.8) \\
\end{array}$ & 3.76 & .855 & Agree \\
\hline $\begin{array}{l}\text { 5. A promotion usually follows from the development } \\
\text { of new and innovative ideas. }\end{array}$ & $\begin{array}{c}41 \\
(9.1) \\
\end{array}$ & $\begin{array}{c}194 \\
(43.1)\end{array}$ & $\begin{array}{c}157 \\
(34.9)\end{array}$ & $\begin{array}{c}52 \\
(11.6)\end{array}$ & $\begin{array}{c}6 \\
(1.3) \\
\end{array}$ & 3.47 & .863 & Agree \\
\hline $\begin{array}{l}\text { 6. Those respondents who come up with innovative } \\
\text { ideas on their own often receive management } \\
\text { encouragement for their activities. }\end{array}$ & $\begin{array}{c}59 \\
(13.1)\end{array}$ & $\begin{array}{c}229 \\
(50.9)\end{array}$ & $\begin{array}{c}127 \\
(28.2)\end{array}$ & $\begin{array}{c}30 \\
(6.7)\end{array}$ & $\begin{array}{c}5 \\
(1.1)\end{array}$ & 3.68 & .825 & Agree \\
\hline $\begin{array}{l}\text { 7. The "doers" on projects are allowed to make } \\
\text { decisions without going through elaborate } \\
\text { justification and approval. }\end{array}$ & $\begin{array}{c}28 \\
(6.2)\end{array}$ & $\begin{array}{c}144 \\
(32.0)\end{array}$ & $\begin{array}{c}145 \\
(32.2)\end{array}$ & $\begin{array}{c}121 \\
(26.9)\end{array}$ & $\begin{array}{c}12 \\
(2.7)\end{array}$ & 3.12 & .965 & Not sure \\
\hline $\begin{array}{l}\text { 8. Senior managers encourage innovators to bend rules } \\
\text { and rigid procedures in order to keep promising ideas } \\
\text { on track. }\end{array}$ & $\begin{array}{c}54 \\
(12.0)\end{array}$ & $\begin{array}{c}254 \\
(56.4)\end{array}$ & $\begin{array}{c}113 \\
(25.1)\end{array}$ & $\begin{array}{c}25 \\
(5.6)\end{array}$ & $\begin{array}{c}4 \\
(0.9)\end{array}$ & 3.73 & .776 & Agree \\
\hline $\begin{array}{l}\text { 9. Many top managers are known for their experience } \\
\text { with the innovation process. }\end{array}$ & $\begin{array}{c}38 \\
(8.4) \\
\end{array}$ & $\begin{array}{c}242 \\
(53.8) \\
\end{array}$ & $\begin{array}{c}132 \\
(29.3)\end{array}$ & $\begin{array}{c}33 \\
(7.3) \\
\end{array}$ & $\begin{array}{c}5 \\
(1.1) \\
\end{array}$ & 3.61 & .788 & Agree \\
\hline $\begin{array}{l}\text { 10. Money is often available to get new project ideas off } \\
\text { the ground. }\end{array}$ & $\begin{array}{c}36 \\
(8.0) \\
\end{array}$ & $\begin{array}{c}182 \\
(40.4)\end{array}$ & $\begin{array}{c}172 \\
(38.2)\end{array}$ & $\begin{array}{c}36 \\
(8.0) \\
\end{array}$ & $\begin{array}{c}24 \\
(5.3) \\
\end{array}$ & 3.38 & .936 & Not sure \\
\hline $\begin{array}{l}\text { 11. Individuals with successful innovative projects } \\
\text { receive additional rewards and compensation for } \\
\text { their ideas and efforts beyond the standard reward } \\
\text { system. }\end{array}$ & $\begin{array}{c}35 \\
(7.8)\end{array}$ & $\begin{array}{c}229 \\
(50.9)\end{array}$ & $\begin{array}{c}128 \\
(28.4)\end{array}$ & $\begin{array}{c}36 \\
(8.0)\end{array}$ & $\begin{array}{c}22 \\
(4.9)\end{array}$ & 3.49 & .928 & Agree \\
\hline $\begin{array}{l}\text { 12. There are several options within the organization for } \\
\text { individuals to get financial support for their } \\
\text { innovative projects and ideas. }\end{array}$ & $\begin{array}{c}30 \\
(6.7)\end{array}$ & $\begin{array}{c}216 \\
(48.0)\end{array}$ & $\begin{array}{c}138 \\
(30.7)\end{array}$ & $\begin{array}{c}43 \\
(9.6)\end{array}$ & $\begin{array}{c}23 \\
(5.1)\end{array}$ & 3.42 & .936 & Agree \\
\hline $\begin{array}{l}\text { 13. People are often encouraged to take calculated risks } \\
\text { with ideas around here. }\end{array}$ & $\begin{array}{c}27 \\
(6.0) \\
\end{array}$ & $\begin{array}{c}192 \\
(42.7) \\
\end{array}$ & $\begin{array}{c}160 \\
(35.6)\end{array}$ & $\begin{array}{c}56 \\
(12.4) \\
\end{array}$ & $\begin{array}{c}15 \\
(3.3) \\
\end{array}$ & 3.36 & .894 & Not sure \\
\hline $\begin{array}{l}\text { 14. Individual risk takers are often recognized for their } \\
\text { willingness to champion new projects, whether } \\
\text { eventually successful or not. }\end{array}$ & $\begin{array}{c}24 \\
(5.3)\end{array}$ & $\begin{array}{c}219 \\
(48.7)\end{array}$ & $\begin{array}{c}127 \\
(28.2)\end{array}$ & $\begin{array}{c}63 \\
(14.0)\end{array}$ & $\begin{array}{c}17 \\
(3.8)\end{array}$ & 3.38 & .922 & Not sure \\
\hline $\begin{array}{l}\text { 15. The tern "risk taker" is considered a positive attribute } \\
\text { for people in my work area. }\end{array}$ & $\begin{array}{c}20 \\
(4.4) \\
\end{array}$ & $\begin{array}{c}214 \\
(47.6)\end{array}$ & $\begin{array}{c}150 \\
(33.1)\end{array}$ & $\begin{array}{c}54 \\
(12.0) \\
\end{array}$ & $\begin{array}{c}12 \\
(2.7) \\
\end{array}$ & 3.39 & .854 & Not sure \\
\hline $\begin{array}{l}\text { 16. This organization supports many small and } \\
\text { experimental projects realizing that some will } \\
\text { undoubtedly fail. }\end{array}$ & $\begin{array}{c}23 \\
(5.1)\end{array}$ & $\begin{array}{c}197 \\
(43.8)\end{array}$ & $\begin{array}{c}163 \\
(36.2)\end{array}$ & $\begin{array}{c}56 \\
(12.4)\end{array}$ & $\begin{array}{c}11 \\
(2.4)\end{array}$ & 3.37 & .855 & Not sure \\
\hline $\begin{array}{l}\text { 17. An employee with a good idea is often given free } \\
\text { time to develop that idea. }\end{array}$ & $\begin{array}{c}36 \\
(8.0) \\
\end{array}$ & $\begin{array}{c}253 \\
(56.2) \\
\end{array}$ & $\begin{array}{c}110 \\
(24.4)\end{array}$ & $\begin{array}{c}41 \\
(9.1) \\
\end{array}$ & $\begin{array}{c}10 \\
(2.2)\end{array}$ & 3.59 & .848 & Agree \\
\hline $\begin{array}{l}\text { 18. There is considerable desire among people in the } \\
\text { organization for generating new ideas without regard } \\
\text { for crossing departmental or functional boundaries. }\end{array}$ & $\begin{array}{c}25 \\
(5.6)\end{array}$ & $\begin{array}{c}188 \\
(41.8)\end{array}$ & $\begin{array}{c}121 \\
(26.9)\end{array}$ & $\begin{array}{c}107 \\
(23.8)\end{array}$ & $\begin{array}{c}9 \\
(2.0)\end{array}$ & 3.25 & .947 & Not sure \\
\hline $\begin{array}{l}\text { 19. People are encouraged to talk to respondents in other } \\
\text { departments of this organization about ideas for new } \\
\text { projects. }\end{array}$ & $\begin{array}{c}57 \\
(12.7)\end{array}$ & $\begin{array}{c}250 \\
(55.6)\end{array}$ & $\begin{array}{c}93 \\
(20.7)\end{array}$ & $\begin{array}{c}46 \\
(10.2)\end{array}$ & $\begin{array}{c}4 \\
(0.9)\end{array}$ & 3.69 & .853 & Agree \\
\hline Management support & $\begin{array}{c}5 \\
(1.1)\end{array}$ & $\begin{array}{c}276 \\
(61.3)\end{array}$ & $\begin{array}{c}149 \\
(33.1)\end{array}$ & $\begin{array}{c}18 \\
(4.0)\end{array}$ & $\begin{array}{c}2 \\
(0.4)\end{array}$ & 3.56 & .551 & Agree \\
\hline
\end{tabular}


Table 4 - Work Discretion of Corporate Entrepreneurship Environment

\begin{tabular}{|c|c|c|c|c|c|c|c|c|}
\hline \multirow[b]{2}{*}{ Corporate entrepreneurship environment } & \multicolumn{5}{|c|}{ Perception Level } & \multirow[b]{2}{*}{$X-$} & \multirow[b]{2}{*}{ S.D. } & \multirow[b]{2}{*}{ Meaning } \\
\hline & 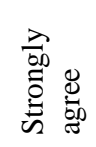 & $\underset{\varpi}{\mathbb{Z}}$ & 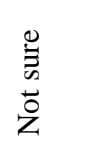 & 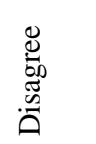 & 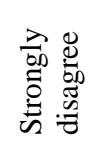 & & & \\
\hline \multicolumn{9}{|l|}{ Work Discretion } \\
\hline $\begin{array}{l}\text { 1. I feel that I am my own boss and do not have to } \\
\text { double-check all of my decisions with someone else. }\end{array}$ & $\begin{array}{c}34 \\
(7.6)\end{array}$ & $\begin{array}{c}140 \\
(31.1)\end{array}$ & $\begin{array}{c}111 \\
(24.7)\end{array}$ & $\begin{array}{c}149 \\
(33.1)\end{array}$ & $\begin{array}{c}16 \\
(3.6)\end{array}$ & 3.06 & 1.042 & Not sure \\
\hline $\begin{array}{l}\text { 2. Harsh criticism and punishment result from mistakes } \\
\text { made on the job. }\end{array}$ & $\begin{array}{c}27 \\
(6.0)\end{array}$ & $\begin{array}{c}131 \\
(29.1)\end{array}$ & $\begin{array}{c}84 \\
(18.7)\end{array}$ & $\begin{array}{c}182 \\
(40.4)\end{array}$ & $\begin{array}{c}26 \\
(5.8)\end{array}$ & 2.89 & 1.076 & Not sure \\
\hline $\begin{array}{l}\text { 3. This organization provides the chance to be creative } \\
\text { and try my own methods of doing the job. }\end{array}$ & $\begin{array}{c}55 \\
(12.2)\end{array}$ & $\begin{array}{c}233 \\
(51.8)\end{array}$ & $\begin{array}{c}112 \\
(24.9)\end{array}$ & $\begin{array}{c}46 \\
(10.2)\end{array}$ & $\begin{array}{c}4 \\
(0.9)\end{array}$ & 3.64 & .857 & Agree \\
\hline $\begin{array}{l}\text { 4. This organization provides the freedom to use my } \\
\text { own judgment. }\end{array}$ & $\begin{array}{c}42 \\
(9.3)\end{array}$ & $\begin{array}{c}252 \\
(56.0)\end{array}$ & $\begin{array}{c}101 \\
(22.4)\end{array}$ & $\begin{array}{c}45 \\
(10.0)\end{array}$ & $\begin{array}{c}10 \\
(2.2)\end{array}$ & 3.60 & .872 & Agree \\
\hline $\begin{array}{l}\text { 5. This organization provides the chance to do } \\
\text { something that makes use of my abilities. }\end{array}$ & $\begin{array}{c}58 \\
(12.9)\end{array}$ & $\begin{array}{c}295 \\
(65.6)\end{array}$ & $\begin{array}{c}69 \\
(15.3)\end{array}$ & $\begin{array}{c}24 \\
(5.3)\end{array}$ & $\begin{array}{c}4 \\
(0.9)\end{array}$ & 3.84 & .743 & Agree \\
\hline 6. I have the freedom to decide what I do on my job. & $\begin{array}{c}70 \\
(15.6)\end{array}$ & $\begin{array}{c}272 \\
(60.4)\end{array}$ & $\begin{array}{c}69 \\
(15.3)\end{array}$ & $\begin{array}{c}34 \\
(7.6)\end{array}$ & $\begin{array}{c}5 \\
(1.1)\end{array}$ & 3.82 & .824 & Agree \\
\hline $\begin{array}{l}\text { 7. It is basically my own responsibility to decide how } \\
\text { my job gets done. }\end{array}$ & $\begin{array}{c}92 \\
(20.4)\end{array}$ & $\begin{array}{c}307 \\
(68.2)\end{array}$ & $\begin{array}{c}36 \\
(8.0)\end{array}$ & $\begin{array}{c}13 \\
(2.9)\end{array}$ & $\begin{array}{c}2 \\
(0.4)\end{array}$ & 4.05 & 662 & Agree \\
\hline 8. I almost always get to decide what I do on my job. & $\begin{array}{c}60 \\
(13.3)\end{array}$ & $\begin{array}{c}275 \\
(61.1)\end{array}$ & $\begin{array}{c}79 \\
(17.6)\end{array}$ & $\begin{array}{c}31 \\
(6.9)\end{array}$ & $\begin{array}{c}5 \\
(1.1)\end{array}$ & 3.79 & .800 & Agree \\
\hline $\begin{array}{l}\text { 9. I have much autonomy on my job and am left on my } \\
\text { own to do my own work. }\end{array}$ & $\begin{array}{c}71 \\
(15.8)\end{array}$ & $\begin{array}{c}267 \\
(59.3)\end{array}$ & $\begin{array}{c}77 \\
(17.1)\end{array}$ & $\begin{array}{c}29 \\
(6.4)\end{array}$ & $\begin{array}{c}6 \\
(1.3)\end{array}$ & 3.82 & .822 & Agree \\
\hline $\begin{array}{l}\text { 10. I seldom have to follow the same work methods or } \\
\text { steps for doing my major tasks from day to day. }\end{array}$ & $\begin{array}{c}37 \\
(8.2)\end{array}$ & $\begin{array}{c}182 \\
(40.4)\end{array}$ & $\begin{array}{c}87 \\
(19.3)\end{array}$ & $\begin{array}{c}131 \\
(29.1)\end{array}$ & $\begin{array}{c}13 \\
(2.9)\end{array}$ & 3.22 & 1.046 & Not sure \\
\hline Work Discretion & $\begin{array}{c}17 \\
(3.8)\end{array}$ & $\begin{array}{c}268 \\
(59.6)\end{array}$ & $\begin{array}{c}146 \\
(32.4)\end{array}$ & $\begin{array}{c}19 \\
(4.2)\end{array}$ & - & 3.57 & .559 & Agree \\
\hline
\end{tabular}

Table 5 - Reward/Reinforcement of Corporate Entrepreneurship Environment Perception Level

\begin{tabular}{|c|c|c|c|c|c|c|c|c|}
\hline \multirow[b]{2}{*}{ Corporate entrepreneurship environment } & \multicolumn{5}{|c|}{ Perception Level } & \multirow[b]{2}{*}{$x-$} & \multirow[b]{2}{*}{ S.D. } & \multirow[b]{2}{*}{ Meaning } \\
\hline & 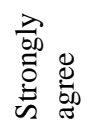 & $\underset{\square}{\stackrel{0}{0}}$ & 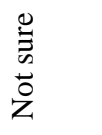 & 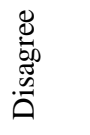 & 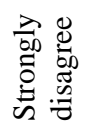 & & & \\
\hline \multicolumn{9}{|l|}{ Rewards/Reinforcement } \\
\hline $\begin{array}{l}\text { 1. My manager helps me get my work } \\
\text { done by removing obstacles and } \\
\text { roadblocks. }\end{array}$ & $\begin{array}{c}53 \\
(11.8)\end{array}$ & $\begin{array}{c}251 \\
(55.8)\end{array}$ & $\begin{array}{c}102 \\
(22.7)\end{array}$ & $\begin{array}{c}39 \\
(8.7)\end{array}$ & $\begin{array}{c}5 \\
(1.1)\end{array}$ & 3.68 & .833 & Agree \\
\hline $\begin{array}{l}\text { 2. The rewards I receive are dependent } \\
\text { upon my work on the job. }\end{array}$ & $\begin{array}{c}70 \\
(15.6)\end{array}$ & $\begin{array}{c}237 \\
(52.7) \\
\end{array}$ & $\begin{array}{c}103 \\
(22.9)\end{array}$ & $\begin{array}{c}27 \\
(6.0) \\
\end{array}$ & $\begin{array}{c}13 \\
(2.9) \\
\end{array}$ & 3.72 & .899 & Agree \\
\hline $\begin{array}{l}\text { 3. My supervisor will increase my job } \\
\text { responsibilities if I am performing well } \\
\text { in my job. }\end{array}$ & $\begin{array}{c}57 \\
(12.7)\end{array}$ & $\begin{array}{c}288 \\
(64.0)\end{array}$ & $\begin{array}{c}82 \\
(18.2)\end{array}$ & $\begin{array}{c}20 \\
(4.4)\end{array}$ & $\begin{array}{c}3 \\
(0.7)\end{array}$ & 3.84 & .722 & Agree \\
\hline $\begin{array}{l}\text { 4. My supervisor will give me special } \\
\text { recognition if my work performance is } \\
\text { especially good. }\end{array}$ & $\begin{array}{c}70 \\
(15.6)\end{array}$ & $\begin{array}{c}226 \\
(50.2)\end{array}$ & $\begin{array}{c}135 \\
(30.0)\end{array}$ & $\begin{array}{c}12 \\
(2.7)\end{array}$ & $\begin{array}{c}7 \\
(1.6) \\
\end{array}$ & 3.76 & .802 & Agree \\
\hline $\begin{array}{l}\text { 5. My manager would tell his/her boss if } \\
\text { my work was outstanding. }\end{array}$ & $\begin{array}{c}65 \\
(14.4) \\
\end{array}$ & $\begin{array}{c}232 \\
(51.6) \\
\end{array}$ & $\begin{array}{c}118 \\
(26.2) \\
\end{array}$ & $\begin{array}{c}29 \\
(6.4) \\
\end{array}$ & $\begin{array}{c}6 \\
(1.3) \\
\end{array}$ & 3.71 & .839 & Agree \\
\hline 6. There is a lot of challenge in my job. & $\begin{array}{c}73 \\
(16.2) \\
\end{array}$ & $\begin{array}{c}242 \\
(53.6)\end{array}$ & $\begin{array}{c}105 \\
(23.3)\end{array}$ & $\begin{array}{c}27 \\
(6.0) \\
\end{array}$ & $\begin{array}{c}3 \\
(0.7) \\
\end{array}$ & 3.79 & .808 & Agree \\
\hline Rewards/Reinforcement & $\begin{array}{c}48 \\
(10.7) \\
\end{array}$ & $\begin{array}{c}294 \\
(65.3) \\
\end{array}$ & $\begin{array}{c}102 \\
(22.7) \\
\end{array}$ & $\begin{array}{c}4 \\
(0.9) \\
\end{array}$ & $\begin{array}{c}2 \\
(0.4) \\
\end{array}$ & 3.75 & .566 & Agree \\
\hline
\end{tabular}


Table 6 - Time Availability of Corporate Entrepreneurship Environment

\begin{tabular}{|c|c|c|c|c|c|c|c|c|}
\hline \multirow[b]{2}{*}{ Corporate entrepreneurship environment } & \multicolumn{5}{|c|}{ Perception Level } & \multirow[b]{2}{*}{$x-$} & \multirow[b]{2}{*}{ S.D. } & \multirow[b]{2}{*}{ Meaning } \\
\hline & 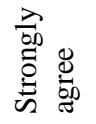 & $\frac{\mathbb{D}}{\square}$ & $\begin{array}{l}0 \\
\vdots \\
\vdots \\
\vdots \\
Z\end{array}$ & 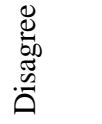 & 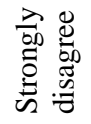 & & & \\
\hline $\begin{array}{l}\text { Time Availability } \\
\text { 1. During the past three months, my } \\
\text { workload kept me from spending time } \\
\text { on developing new ideas. }\end{array}$ & $\begin{array}{c}33 \\
(7.3)\end{array}$ & $\begin{array}{c}190 \\
(42.2)\end{array}$ & $\begin{array}{c}96 \\
(21.3)\end{array}$ & $\begin{array}{c}119 \\
(26.4)\end{array}$ & $\begin{array}{c}12 \\
(2.7)\end{array}$ & 3.25 & 1.013 & Not sure \\
\hline $\begin{array}{l}\text { 2. I always seem to have plenty of time } \\
\text { to get everything done. }\end{array}$ & $\begin{array}{c}26 \\
(5.8) \\
\end{array}$ & $\begin{array}{c}197 \\
(43.8) \\
\end{array}$ & $\begin{array}{c}136 \\
(30.2) \\
\end{array}$ & $\begin{array}{c}82 \\
(18.2) \\
\end{array}$ & $\begin{array}{c}9 \\
(2.0) \\
\end{array}$ & 3.33 & .907 & Not sure \\
\hline $\begin{array}{l}\text { 3. I have just the right amount of time } \\
\text { and workload to do everything well. }\end{array}$ & $\begin{array}{c}31 \\
(6.9) \\
\end{array}$ & $\begin{array}{c}244 \\
(54.2) \\
\end{array}$ & $\begin{array}{c}100 \\
(22.2) \\
\end{array}$ & $\begin{array}{c}69 \\
(15.3) \\
\end{array}$ & $\begin{array}{c}6 \\
(1.3) \\
\end{array}$ & 3.50 & .881 & Agree \\
\hline $\begin{array}{l}\text { 4. My job is structured so that I have } \\
\text { very little time to think about wider } \\
\text { organizational problems. }\end{array}$ & $\begin{array}{c}28 \\
(6.2)\end{array}$ & $\begin{array}{c}188 \\
(41.8)\end{array}$ & $\begin{array}{c}98 \\
(21.8)\end{array}$ & $\begin{array}{c}128 \\
(28.4)\end{array}$ & $\begin{array}{c}8 \\
(1.8)\end{array}$ & 3.22 & .987 & Not sure \\
\hline $\begin{array}{l}\text { 5. I feel that I am always working with } \\
\text { time constraints on my job. }\end{array}$ & $\begin{array}{c}44 \\
(9.8) \\
\end{array}$ & $\begin{array}{c}215 \\
(47.8) \\
\end{array}$ & $\begin{array}{c}90 \\
(20.0)\end{array}$ & $\begin{array}{c}90 \\
(20.0)\end{array}$ & $\begin{array}{c}11 \\
(2.4) \\
\end{array}$ & 3.42 & .994 & Agree \\
\hline $\begin{array}{l}\text { 6. My co-workers and I always find time } \\
\text { for long-term problem solving. }\end{array}$ & $\begin{array}{c}36 \\
(8.0)\end{array}$ & $\begin{array}{c}145 \\
(32.2)\end{array}$ & $\begin{array}{c}142 \\
(31.6)\end{array}$ & $\begin{array}{c}116 \\
(25.8)\end{array}$ & $\begin{array}{c}11 \\
(2.4)\end{array}$ & 3.18 & .984 & Not sure \\
\hline Time Availability & $\begin{array}{c}11 \\
(2.4) \\
\end{array}$ & $\begin{array}{c}168 \\
(37.3) \\
\end{array}$ & $\begin{array}{c}260 \\
(57.8) \\
\end{array}$ & $\begin{array}{c}11 \\
(2.4) \\
\end{array}$ & - & 3.32 & .480 & Not sure \\
\hline
\end{tabular}

Table 7 - Organizational Boundaries of Corporate Entrepreneurship Environment

\begin{tabular}{|c|c|c|c|c|c|c|c|c|}
\hline \multirow[b]{2}{*}{ Corporate entrepreneurship environment } & \multicolumn{5}{|c|}{ Perception Level } & \multirow[b]{2}{*}{$X-$} & \multirow[b]{2}{*}{ S.D. } & \multirow[b]{2}{*}{ Meaning } \\
\hline & 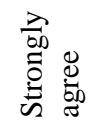 & 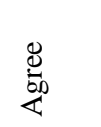 & 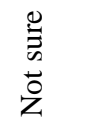 & 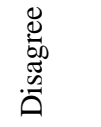 & 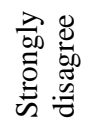 & & & \\
\hline \multicolumn{9}{|l|}{ Organizational Boundaries } \\
\hline $\begin{array}{l}\text { 1. In the past three months, I have always followed } \\
\text { standard operating procedures or practices to do my } \\
\text { major tasks. }\end{array}$ & $\begin{array}{c}47 \\
(10.4)\end{array}$ & $\begin{array}{c}226 \\
(50.2)\end{array}$ & $\begin{array}{c}47 \\
(10.4)\end{array}$ & $\begin{array}{c}122 \\
(27.1)\end{array}$ & $\begin{array}{c}8 \\
(1.8)\end{array}$ & 3.40 & 1.049 & Not sure \\
\hline $\begin{array}{l}\text { 2. There are many written rules and procedures that } \\
\text { exist for doing my major tasks. }\end{array}$ & $\begin{array}{c}47 \\
(10.4)\end{array}$ & $\begin{array}{c}198 \\
(44.0)\end{array}$ & $\begin{array}{c}53 \\
(11.8)\end{array}$ & $\begin{array}{c}147 \\
(32.7)\end{array}$ & $\begin{array}{c}5 \\
(1.1)\end{array}$ & 3.30 & 1.068 & Not sure \\
\hline 3. On my job I have no doubt of what is expected of me. & $\begin{array}{c}56 \\
(12.4)\end{array}$ & $\begin{array}{c}271 \\
(60.2)\end{array}$ & $\begin{array}{c}104 \\
(23.1)\end{array}$ & $\begin{array}{c}16 \\
(3.6)\end{array}$ & $\begin{array}{c}3 \\
(0.7)\end{array}$ & 3.80 & .721 & Agree \\
\hline 4. There is little uncertainty in my job. & $\begin{array}{c}37 \\
(8.2)\end{array}$ & $\begin{array}{c}257 \\
(57.1) \\
\end{array}$ & $\begin{array}{c}124 \\
(27.6)\end{array}$ & $\begin{array}{c}28 \\
(6.2)\end{array}$ & $\begin{array}{c}4 \\
(0.9)\end{array}$ & 3.66 & .755 & Agree \\
\hline $\begin{array}{l}\text { 6. My job description clearly specifies the standards of } \\
\text { performance on which my job is evaluated. }\end{array}$ & $\begin{array}{c}51 \\
(11.3)\end{array}$ & $\begin{array}{c}182 \\
(40.4)\end{array}$ & $\begin{array}{c}73 \\
(16.2)\end{array}$ & $\begin{array}{c}131 \\
(29.1)\end{array}$ & $\begin{array}{c}13 \\
(2.9)\end{array}$ & 3.28 & 1.090 & Not sure \\
\hline $\begin{array}{l}\text { 7. I clearly know what level of work performance is } \\
\text { expected from me in terms of amount, quality, and } \\
\text { time line of output. }\end{array}$ & $\begin{array}{c}64 \\
(14.2)\end{array}$ & $\begin{array}{c}308 \\
(68.4)\end{array}$ & $\begin{array}{c}63 \\
(14.0)\end{array}$ & $\begin{array}{c}12 \\
(2.7)\end{array}$ & $\begin{array}{c}3 \\
(0.7)\end{array}$ & 3.98 & .667 & Agree \\
\hline Organizational Boundaries & $\begin{array}{c}14 \\
(3.1)\end{array}$ & $\begin{array}{c}223 \\
(49.6)\end{array}$ & $\begin{array}{c}210 \\
(46.7)\end{array}$ & $\begin{array}{c}3 \\
(0.7)\end{array}$ & - & 3.53 & .492 & Agree \\
\hline
\end{tabular}


Table 8 - Number Percentage Mean and Standard Deviation of Job Satisfaction

\begin{tabular}{|c|c|c|c|c|c|c|c|c|}
\hline \multirow[b]{2}{*}{ Job satisfaction } & \multicolumn{5}{|c|}{ Satisfaction Level } & \multirow[b]{2}{*}{$X-$} & \multirow[b]{2}{*}{ S.D. } & \multirow[b]{2}{*}{ Meaning } \\
\hline & 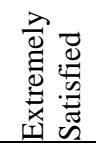 & 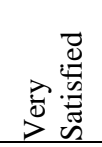 & 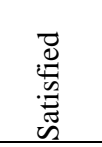 & 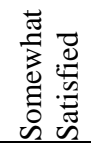 & 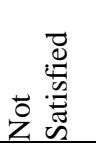 & & & \\
\hline 1. Being able to keep busy all the time. & $\begin{array}{c}36 \\
(8.0)\end{array}$ & $\begin{array}{c}79 \\
(17.6)\end{array}$ & $\begin{array}{c}178 \\
(39.6)\end{array}$ & $\begin{array}{c}135 \\
(30.0)\end{array}$ & $\begin{array}{c}22 \\
(4.9)\end{array}$ & 2.94 & .995 & Satisfied \\
\hline 2. The chance to work alone on the job. & $\begin{array}{l}30 \\
(6.7)\end{array}$ & $\begin{array}{c}96 \\
(21.3)\end{array}$ & $\begin{array}{c}183 \\
(40.7)\end{array}$ & $\begin{array}{c}122 \\
(27.1)\end{array}$ & $\begin{array}{c}19 \\
(4.2)\end{array}$ & 2.99 & .960 & Satisfied \\
\hline $\begin{array}{l}\text { 3. The chance to do different things from time to } \\
\text { time. }\end{array}$ & $\begin{array}{c}39 \\
(8.7) \\
\end{array}$ & $\begin{array}{c}141 \\
(31.3)\end{array}$ & $\begin{array}{c}202 \\
(44.9)\end{array}$ & $\begin{array}{c}63 \\
(14.0) \\
\end{array}$ & $\begin{array}{c}5 \\
(1.1) \\
\end{array}$ & 3.32 & .861 & Satisfied \\
\hline 4. The chance to be "somebody" in the community. & $\begin{array}{c}61 \\
(13.6)\end{array}$ & $\begin{array}{c}148 \\
(32.9)\end{array}$ & $\begin{array}{c}179 \\
(39.8)\end{array}$ & $\begin{array}{c}55 \\
(12.2)\end{array}$ & $\begin{array}{c}7 \\
(1.6)\end{array}$ & 3.45 & .926 & $\begin{array}{l}\text { Very } \\
\text { Satisfied }\end{array}$ \\
\hline 5. The way my boss handles his/her workers. & $\begin{array}{c}21 \\
(4.7)\end{array}$ & $\begin{array}{c}120 \\
(26.7)\end{array}$ & $\begin{array}{c}199 \\
(44.2)\end{array}$ & $\begin{array}{c}91 \\
(20.2) \\
\end{array}$ & $\begin{array}{c}19 \\
(4.2) \\
\end{array}$ & 3.07 & .906 & Satisfied \\
\hline $\begin{array}{l}\text { 6. The competence of my supervisor in making } \\
\text { decisions. }\end{array}$ & $\begin{array}{c}33 \\
(7.3) \\
\end{array}$ & $\begin{array}{c}127 \\
(28.2)\end{array}$ & $\begin{array}{c}197 \\
(43.8) \\
\end{array}$ & $\begin{array}{c}74 \\
(16.4)\end{array}$ & $\begin{array}{c}19 \\
(4.2) \\
\end{array}$ & 3.18 & .937 & Satisfied \\
\hline $\begin{array}{l}\text { 7. Being able to do things that don't go against my } \\
\text { conscience. }\end{array}$ & $\begin{array}{c}74 \\
(16.4)\end{array}$ & $\begin{array}{c}183 \\
(40.7)\end{array}$ & $\begin{array}{c}141 \\
(31.3)\end{array}$ & $\begin{array}{c}38 \\
(8.4)\end{array}$ & $\begin{array}{c}14 \\
(3.1) \\
\end{array}$ & 3.59 & .964 & $\begin{array}{l}\text { Very } \\
\text { Satisfied }\end{array}$ \\
\hline 8. The way my job provides for steady employment. & $\begin{array}{c}74 \\
(16.4)\end{array}$ & $\begin{array}{c}177 \\
(39.3)\end{array}$ & $\begin{array}{c}167 \\
(37.1)\end{array}$ & $\begin{array}{c}25 \\
(5.6) \\
\end{array}$ & $\begin{array}{c}7 \\
(1.6) \\
\end{array}$ & 3.64 & .876 & $\begin{array}{l}\text { Very } \\
\text { Satisfied }\end{array}$ \\
\hline 9. The chance to do things for other people. & $\begin{array}{c}68 \\
(15.1) \\
\end{array}$ & $\begin{array}{c}175 \\
(38.9)\end{array}$ & $\begin{array}{c}174 \\
(38.7) \\
\end{array}$ & $\begin{array}{c}32 \\
(7.1) \\
\end{array}$ & $\begin{array}{c}1 \\
(0.2) \\
\end{array}$ & 3.62 & .834 & $\begin{array}{l}\text { Very } \\
\text { Satisfied } \\
\end{array}$ \\
\hline 10. The chance to tell people what to do. & $\begin{array}{c}43 \\
(9.6) \\
\end{array}$ & $\begin{array}{c}159 \\
(35.3) \\
\end{array}$ & $\begin{array}{c}206 \\
(45.8) \\
\end{array}$ & $\begin{array}{c}40 \\
(8.9) \\
\end{array}$ & $\begin{array}{c}2 \\
(0.4) \\
\end{array}$ & 3.45 & .803 & $\begin{array}{l}\text { Very } \\
\text { Satisfied } \\
\end{array}$ \\
\hline $\begin{array}{l}\text { 11. The chance to do something that makes use of my } \\
\text { abilities. }\end{array}$ & $\begin{array}{c}68 \\
(15.1) \\
\end{array}$ & $\begin{array}{c}182 \\
(40.4)\end{array}$ & $\begin{array}{c}169 \\
(37.6)\end{array}$ & $\begin{array}{c}29 \\
(6.4) \\
\end{array}$ & $\begin{array}{c}2 \\
(0.4) \\
\end{array}$ & 3.63 & .832 & $\begin{array}{l}\text { Very } \\
\text { Satisfied }\end{array}$ \\
\hline 12. The way company policies are put into practice. & $\begin{array}{c}29 \\
(6.4) \\
\end{array}$ & $\begin{array}{c}151 \\
(33.6)\end{array}$ & $\begin{array}{c}207 \\
(46.0)\end{array}$ & $\begin{array}{c}51 \\
(11.3) \\
\end{array}$ & $\begin{array}{c}12 \\
(2.7) \\
\end{array}$ & 3.30 & .852 & Satisfied \\
\hline 13. My pay and the amount of work I do. & $\begin{array}{c}26 \\
(5.8) \\
\end{array}$ & $\begin{array}{c}126 \\
(28.0) \\
\end{array}$ & $\begin{array}{c}212 \\
(47.1) \\
\end{array}$ & $\begin{array}{c}52 \\
(11.6) \\
\end{array}$ & $\begin{array}{c}34 \\
(7.6) \\
\end{array}$ & 3.13 & .956 & Satisfied \\
\hline 14. The chances for advancement on this job. & $\begin{array}{c}44 \\
(9.8) \\
\end{array}$ & $\begin{array}{c}116 \\
(25.8)\end{array}$ & $\begin{array}{c}203 \\
(45.1) \\
\end{array}$ & $\begin{array}{c}62 \\
(13.8) \\
\end{array}$ & $\begin{array}{c}25 \\
(5.6) \\
\end{array}$ & 3.20 & .985 & Satisfied \\
\hline 15. The freedom to use my own judgment. & $\begin{array}{c}45 \\
(10.0) \\
\end{array}$ & $\begin{array}{c}160 \\
(35.6)\end{array}$ & $\begin{array}{c}184 \\
(40.9)\end{array}$ & $\begin{array}{c}46 \\
(10.2) \\
\end{array}$ & $\begin{array}{c}15 \\
(3.3) \\
\end{array}$ & 3.39 & .918 & Satisfied \\
\hline $\begin{array}{l}\text { 16. The chance to try my own methods of doing the } \\
\text { job. }\end{array}$ & $\begin{array}{c}35 \\
(7.8) \\
\end{array}$ & $\begin{array}{c}162 \\
(36.0) \\
\end{array}$ & $\begin{array}{c}186 \\
(41.3) \\
\end{array}$ & $\begin{array}{c}56 \\
(12.4) \\
\end{array}$ & $\begin{array}{c}11 \\
(2.4) \\
\end{array}$ & 3.34 & .882 & Satisfied \\
\hline 17. The working conditions. & $\begin{array}{c}33 \\
(7.3) \\
\end{array}$ & $\begin{array}{c}147 \\
(32.7) \\
\end{array}$ & $\begin{array}{c}214 \\
(47.6) \\
\end{array}$ & $\begin{array}{c}39 \\
(8.7) \\
\end{array}$ & $\begin{array}{c}17 \\
(3.8) \\
\end{array}$ & 3.31 & .873 & Satisfied \\
\hline 18. The way my co-workers get along with each other. & $\begin{array}{c}51 \\
(11.3) \\
\end{array}$ & $\begin{array}{c}156 \\
(34.7) \\
\end{array}$ & $\begin{array}{c}210 \\
(46.7)\end{array}$ & $\begin{array}{c}27 \\
(6.0) \\
\end{array}$ & $\begin{array}{c}6 \\
(1.3) \\
\end{array}$ & 3.49 & .823 & $\begin{array}{l}\text { Very } \\
\text { Satisfied }\end{array}$ \\
\hline 19. The praise I get for doing a good job. & $\begin{array}{c}52 \\
(11.6) \\
\end{array}$ & $\begin{array}{c}146 \\
(32.4) \\
\end{array}$ & $\begin{array}{c}206 \\
(45.8) \\
\end{array}$ & $\begin{array}{c}41 \\
(9.1) \\
\end{array}$ & $\begin{array}{c}5 \\
(1.1) \\
\end{array}$ & 3.44 & .853 & $\begin{array}{l}\text { Very } \\
\text { Satisfied }\end{array}$ \\
\hline 20. The feeling of accomplishment I get from the job & $\begin{array}{c}121 \\
(26.9) \\
\end{array}$ & $\begin{array}{c}137 \\
(30.4) \\
\end{array}$ & $\begin{array}{c}158 \\
(35.1) \\
\end{array}$ & $\begin{array}{c}29 \\
(6.4) \\
\end{array}$ & $\begin{array}{c}5 \\
(1.1) \\
\end{array}$ & 3.76 & .959 & $\begin{array}{l}\text { Very } \\
\text { Satisfied }\end{array}$ \\
\hline Job satisfaction & $\begin{array}{c}12 \\
(2.7) \\
\end{array}$ & $\begin{array}{c}168 \\
(37.3) \\
\end{array}$ & $\begin{array}{c}240 \\
(53.3) \\
\end{array}$ & $\begin{array}{c}30 \\
(6.4) \\
\end{array}$ & - & 3.36 & .580 & Satisfied \\
\hline
\end{tabular}


Table 9 - The Results of Hypothesis Testing 1

\begin{tabular}{|c|c|c|c|c|c|}
\hline No. & Independent Variables & Dependent Variable & Statistical & $p$ & Results \\
\hline 1 & Gender & Management Support & $T$-test & .138 & Not rejected $\mathrm{H}_{0}$ \\
\hline 2 & Gender & Work discretion & $T$-test & .005 & Rejected $\mathrm{H}_{0}$ \\
\hline 3 & Gender & Rewards/reinforcement & T-test & .029 & Rejected $\mathrm{H}_{0}$ \\
\hline 4 & Gender & Time availability & $T$-test & .339 & Not rejected $\mathrm{H}_{0}$ \\
\hline 5 & Gender & Organizational boundaries & T-test & .088 & Not rejected $\mathrm{H}_{0}$ \\
\hline 6 & Age & Management Support & $F$-test & .336 & Not rejected $\mathrm{H}_{0}$ \\
\hline 7 & Age & Work discretion & $F$-test & .262 & Not rejected $\mathrm{H}_{0}$ \\
\hline 8 & Age & Rewards/reinforcement & $F$-test & .210 & Not rejected $\mathrm{H}_{0}$ \\
\hline 9 & Age & Time availability & $F$-test & .028 & Rejected H0 \\
\hline 10 & Age & Organizational boundaries & $F$-test & .038 & Rejected HO \\
\hline 11 & Education Level & Management Support & T-test & .000 & Rejected $\mathrm{H}_{0}$ \\
\hline 12 & Education Level & Work discretion & $T$-test & .001 & Rejected $\mathrm{H}_{0}$ \\
\hline 13 & Education Level & Rewards/reinforcement & $T$-test & .000 & Rejected $\mathrm{H}_{0}$ \\
\hline 14 & Education Level & Time availability & $T$-test & .758 & Not rejected $\mathrm{H}_{0}$ \\
\hline 15 & Education Level & Organizational boundaries & T-test & .622 & Not rejected $\mathrm{H}_{0}$ \\
\hline 16 & Occupation & Management Support & $F$-test & .000 & Rejected $\mathrm{H}_{0}$ \\
\hline 17 & Occupation & Work discretion & $F$-test & .000 & Rejected $\mathrm{H}_{0}$ \\
\hline 18 & Occupation & Rewards/reinforcement & $F$-test & .044 & Rejected $\mathrm{H}_{0}$ \\
\hline 19 & Occupation & Time availability & $F$-test & .106 & Not rejected $\mathrm{H}_{0}$ \\
\hline 20 & Occupation & Organizational boundaries & F-test & .000 & Rejected $\mathrm{H}_{0}$ \\
\hline 21 & Position & Management Support & $F$-test & .000 & Rejected $\mathrm{H}_{0}$ \\
\hline 22 & Position & Work discretion & $F$-test & .000 & Rejected $\mathrm{H}_{0}$ \\
\hline 23 & Position & Rewards/reinforcement & $F$-test & .000 & Rejected $\mathrm{H}_{0}$ \\
\hline 24 & Position & Time availability & $F$-test & .074 & Not rejected $\mathrm{H}_{0}$ \\
\hline 25 & Position & Organizational boundaries & $F$-test & .081 & Not rejected $\mathrm{H}_{0}$ \\
\hline 26 & Salary & Management Support & $F$-test & .000 & Rejected $\mathrm{H}_{0}$ \\
\hline 27 & Salary & Work discretion & $F$-test & .000 & Rejected $\mathrm{H}_{0}$ \\
\hline 28 & Salary & Rewards/reinforcement & $F$-test & .001 & Rejected $\mathrm{H}_{0}$ \\
\hline 29 & Salary & Time availability & $F$-test & .065 & Not rejected $\mathrm{H}_{0}$ \\
\hline 30 & Salary & Organizational boundaries & $F$-test & .032 & Rejected $\mathrm{H}_{0}$ \\
\hline 31 & Company type & Management Support & $F$-test & .000 & Rejected $\mathrm{H}_{0}$ \\
\hline 32 & Company type & Work discretion & $F$-test & .000 & Rejected $\mathrm{H}_{0}$ \\
\hline 33 & Company type & Rewards/reinforcement & $F$-test & .000 & Rejected $\mathrm{H}_{0}$ \\
\hline 34 & Company type & Time availability & $F$-test & .514 & Not rejected $\mathrm{H}_{0}$ \\
\hline 35 & Company type & Organizational boundaries & F-test & .000 & Rejected $\mathrm{H}_{0}$ \\
\hline 36 & Sale volume per annum & Management Support & $F$-test & .016 & Not rejected $\mathrm{H}_{0}$ \\
\hline 37 & Sale volume per annum & Work discretion & $F$-test & .170 & Not rejected $\mathrm{H}_{0}$ \\
\hline 38 & Sale volume per annum & Rewards/reinforcement & $F$-test & .982 & Not rejected $\mathrm{H}_{0}$ \\
\hline 39 & Sale volume per annum & Time availability & F-test & .359 & Not rejected $\mathrm{H}_{0}$ \\
\hline 40 & Sale volume per annum & Organizational boundaries & $F$-test & .000 & Rejected $\mathrm{H}_{0}$ \\
\hline 41 & Employee number & Management Support & F-test & .173 & Not rejected $\mathrm{H}_{0}$ \\
\hline 42 & Employee number & Work discretion & $F$-test & .160 & Not rejected $\mathrm{H}_{0}$ \\
\hline 43 & Employee number & Rewards/reinforcement & $F$-test & .858 & Not rejected $\mathrm{H}_{0}$ \\
\hline 44 & Employee number & Time availability & $F$-test & .532 & Not rejected $\mathrm{H}_{0}$ \\
\hline 45 & Employee number & Organizational boundaries & $F$-test & .000 & Rejected $\mathrm{H}_{0}$ \\
\hline 46 & Business type & Management Support & $F$-test & .004 & Rejected $\mathrm{H}_{0}$ \\
\hline 47 & Business type & Work discretion & $F$-test & .037 & Rejected $\mathrm{H}_{0}$ \\
\hline 48 & Business type & Rewards/reinforcement & $F$-test & .029 & Rejected $\mathrm{H}_{0}$ \\
\hline 49 & Business type & Time availability & $F$-test & .142 & Not rejected $\mathrm{H}_{0}$ \\
\hline 50 & Business type & Organizational boundaries & $F$-test & .000 & Rejected $\mathrm{H}_{0}$ \\
\hline
\end{tabular}


Table 10 - The Results of Hypothesis Testing 2

\begin{tabular}{clcccc}
\hline No. & Independent Variables & Dependent Variable & Statistical & $\boldsymbol{p}$ & Results \\
\hline 1 & gender & Job satisfaction & T-test & .023 & Rejected $\mathrm{H}_{0}$ \\
2 & Age & Job satisfaction & $F$-test & .005 & Rejected $\mathrm{H}_{0}$ \\
3 & Education Level & Job satisfaction & T-test & .009 & Rejected $\mathrm{H}_{0}$ \\
4 & Occupation & Job satisfaction & $F$-test & .000 & Rejected $\mathrm{H}_{0}$ \\
5 & Position & Job satisfaction & $F$-test & .000 & ${\text { Rejected } \mathrm{H}_{0}}$ \\
6 & Salary & Job satisfaction & $F$-test & .000 & Rejected $\mathrm{H}_{0}$ \\
7 & Company type & Job satisfaction & $F$-test & .119 & Not rejected $\mathrm{H}_{0}$ \\
8 & Sale volume per annum & Job satisfaction & $F$-test & .008 & Rejected $\mathrm{H}_{0}$ \\
9 & employee number & Job satisfaction & F-test & .081 & Rejected $\mathrm{H}_{0}$ \\
10 & Business type & Job satisfaction & $F$-test & .013 & Rejected $\mathrm{H}_{0}$ \\
\hline
\end{tabular}

Table 11 - The Results of Hypothesis Testing 3

\begin{tabular}{clcccc}
\hline No. & Independent Variables & Dependent Variable & Statistical & $\boldsymbol{p}$ & Results \\
\hline 1 & Management Support & Job satisfaction & $r$ & $.348^{*}$ & Rejected $\mathrm{H}_{0}$ \\
2 & Work discretion & Job satisfaction & $r$ & $.470^{*}$ & Rejected $\mathrm{H}_{0}$ \\
3 & Rewards/reinforcement & Job satisfaction & $r$ & $.432^{*}$ & Rejected $\mathrm{H}_{0}$ \\
4 & Time availability & Job satisfaction & $r$ & $.222^{*}$ & Rejected $\mathrm{H}_{0}$ \\
5 & Organizational boundaries & Job satisfaction & $r$ & $.441^{*}$ & Rejected $\mathrm{H}_{0}$ \\
\hline
\end{tabular}

